\title{
ENHANCED COALBED METHANE IN NIGERIA: ONYEAMA COALBED
}

\author{
Abu Robin Nyemenim ${ }^{1}$, Cyrus Aseibichin ${ }^{2}$, Adeloye Olalekan Michael ${ }^{3}$, Wilcox Ziebiye Zaccheaus ${ }^{4}$ \\ ${ }^{I}$ PhD study in Energy, Cranfield University Bedfordshire, United Kingdom \\ ${ }^{2}$ PhD study in Chemical Engineering, Rivers State University of Science and Technology, Port Harcourt, Nigeria \\ ${ }^{3} \mathrm{PhD}$ study in Chemical Engineering, Rivers State University of Science and Technology, Port Harcourt, Nigeria \\ ${ }^{4}$ Master of Technology study in Chemical Engineering, Rivers State University of Science and Technology, Port \\ Harcourt, Nigeria
}

\begin{abstract}
Carbondioxde enhanced coalbed methane $\left(\mathrm{CO}_{2}-\mathrm{ECBM}\right)$ production from Onyeama coalbed field in Anambra basin, Nigeria was simulated using Eclipse 300 simulator in vertical and horizontal well orientations, with the resulting production compared with coalbed methane(CBM) production from the well in both orientations. The simulation was construed for 25 years and cumulative production result from carbondioxide enhanced coalbed methane in vertical and horizontal well and coalbed methane in vertical and horizontal well yields 10466.60MMSCF, 45648.42MMSCF and 6501.81MMSCF, 19866.10MMSCF respectively. The recovery factors of carbondioxide enhanced coalbed methane and coalbed methane production from Onyeama coalbed in vertical and horizontal orientations are $8.03 \%, 35.04 \%$ and $4.99 \%, 15.2 \%$ respectively. Thus, carbondioxide enhanced coalbed methane shows higher recovery factor as compared with coalbed methane, thereby leading to increase or improve production from Onyeama coalbed field with carbondioxide enhanced coalbed methane in horizontal well orientation yielding the highest recovery factor and least coal gas de-concentration. Hence, coal gas de-concentration and recovery factor are influenced by the developmental or production method and they are used as measures for selecting most efficient developmental process.
\end{abstract}

Keywords: Carbondioxide Enhanced Coalbed Methane, Coalbed Methane, Onyeama Coalbed Field, Vertical Coalbed Well, Horizontal Coalbed Well, Eclipse 300 Simulator, Coal Gas Concentration, Recovery Factor.

\section{INTRODUCTION}

The increasing demand for clean energy forces the world to search for alternatives to conventional energy resources such as coalbed methane, tight gas, shale gas, gas hydrates etc. Coalbed Methane (CBM) is an unconventional hydrocarbon resource that fundamentally differs in its accumulation processes and production technology when compared to conventional natural gas resources. Coalbed methane is generated during coalification process, that is, the chemical transformation process from vegetation into coal, which involves the transformation of the complex biological and molecular structures in the cells of plants into the chemical fragments and structures seen in coal that gets adsorbed on coal at higher pressure. Presence of CBM in underground mine not only makes mining works difficult and risky, but also makes it costly and its ventilation to atmosphere adds greenhouse gas causing global warming ${ }^{1}$.

Generally, convectional techniques are usually applicable for exploitation of coalbed methane reserves, these conventional methods for CBM extraction resulted in less economical gas production. Therefore, some advanced method is considered for enhancing coalbed methane production. Among the enhanced coalbed methane production techniques, the most environmentally friendly and economical method is injection of carbondioxide and nitrogen gas into formation in order to produce methane ${ }^{2}$.
Reviewing the current coalbed methane production technologies, two general methods for extraction of methane are deduced.

- Pre-mining drainage methods: Pre-mining drainage involves removing of methane prior to mining of a virgin coal seam by drilling of borehole from the surface into virgin coal seam. Pre-mining drainage is generally ineffective in low permeability seams. However, Hydraulic fracturing, blasting, and chemical reactions have proved effective for increasing the permeability of coal.

- Post-Mining drainage methods: The objective of post mining drainage is to maximize the rate of gas removal from the underground mining districts and hence minimize gas flow into the mine airways. It involves drilling angled boreholes, and in some instances below the goaf, close to the coalface and connecting them to a pipe network. The recovery of gas is assisted by the application of suction provided by pump sited either underground in a return airway or at the surface in a purpose built methane plant.

Several difficulties are associated with the recovery of coalbed methane gas from coal beds such as process of methane desorption from coal (gas desorption is accompanied by swelling of the body of coal), stimulation of coal medium and maintaining proper exploitation conditions ${ }^{3}$. 
Methane can primarily be produced from coal bed reservoirs, by the process of formation water removal (Dewatering) thus reducing the partial pressure of the methane alone, while sustaining reservoir pressure. The pressure reduction frees the methane from the coal and allows gas migration. Methane gas which is desorbed from coal due to the hydrostatic pressure reduction at depth is free to migrate through permeable strata, cleats and fractures to an area of lower pressure, ideally into the wellbores that created the pressure reduction from where it is channeled to the surface facility. The first stage in the production life of this kind of reservoir is the dewatering stage, the second stage (midlife) denotes a stable or continuous increase production and the third stage is the decline of gas production rate until abandonment of production ${ }^{4}$.

Carbondioxide enhanced coalbed methane (ECBM) involves injection of carbondioxide into the coal seam which gets adsorbed in preference to methane which is desorbed from the coal seam; this procedure provides dual benefits of enhanced coalbed methane recovery and carbon sequestration. Carbondioxide sourced naturally or from anthropogenic means can be used for ECBM operations. It is therefore possible to have a cost effective, closed and safe circle of power generation in which the local power station, powered by coalbed methane has its carbondioxide emission sequestered in the same seam that provides the methane. There are three main methods which can induce methane release from coal':

- $\quad$ Reduce the overall pressure, usually by dewatering the formation either through pumping or mining.

- $\quad$ Reduce the partial pressure of the methane by injecting another inert gas into the formation.

- Replace the methane on the surface with another compound, such as carbondioxide.

Therefore, the main difficulties in maximizing the potential of coalbed methane production ranges from the country's specific fiscal policy regulation and minimizing the development cost (particularly drilling and completion cost $)^{6}$. The unique characteristics of Coalbed reservoirs demand a novel approach in well construction, formation evaluation, completion and stimulation fluids, modeling and reservoir development. Considering the unique nature of the various coal basins in Nigeria, the problems associated with exploitation of coalbed methane (CBM) in Nigeria includes mapping coal bed methane reservoirs, identifying factors that influence reservoir heterogeneity and permeability, hydrologic factors that control storage and release of methane in a coal seam, dewatering process for disposal of produced water at the lowest possible cost and in an environmental friendly manner, obtaining critical reservoir parameters that control production and calculating reserves and making long-term production forecast ${ }^{7}$.

This study describes, investigate and analyse carbondioxide enhanced coalbed methane production $\left(\mathrm{CO}_{2}\right.$-ECBM) from Onyeama coalbed field in vertical and horizontal well and compare the production or simulation output with coalbed methane production(CBM) in vertical and horizontal well from the same coalbed field by using Eclipse 300 simulator, based on cumulative production, coal gas concentrations and recovery factors.

\section{METHODOLOGY}

Eclipse 300 simulator was applicable in coalbed methane simulation analysis by carbondioxide enhanced coalbed methane $\left(\mathrm{CO}_{2}\right.$-ECBM) production from Onyeama coalbed field, Anambra basin, eastern Nigeria in vertical and horinzontal well analysis. The simulation or production result was analysed and compared with simulation output of coalbed methane production in Nigeria: Onyeama coalbed field in both vertical and horizontal well. Cartesian and corner grids pattern were construed with dimension 8 by 8 by 2 for accurate coalbed reservoir modeling and single phase hydrocarbon coalbed methane defined. The reservoir contents such as ash content, fixed carbon, volatile matter, moisture and elemental contents were deduced by using proximate and ultimate analysis. Also determination of average depth, pressure at each average depth and determination of the volume of gas content for each grid by using Langmuir equation. Reservoir data of Onyeama Coalbed field applicable in this simulation analysis is inferred from coalbed methane production in Nigeria.

\subsection{Gas Content Estimation}

The characterization of the Langmuir isotherm commonly used to model the gas content, which provides a guide to gas content of the coal of any field at any time as pressure is decreased while production proceeds through the life cycle of the well is expressed as:

$$
\mathrm{GC}_{-} \mathrm{L}=\mathrm{L}_{\mathrm{C}} *\left\{1-\mathrm{M}_{\mathrm{C}}+\mathrm{A}_{\mathrm{C}}\right\} /\left\{\mathrm{P}_{\mathrm{R}} /\left(\mathrm{P}_{\mathrm{R}}+\mathrm{P}_{\mathrm{C}}\right)\right\}
$$

\subsection{Gas in Place (GIP) Estimation}

The total gas in place (GIP) is expressed in terms of project area, coal tonnage, and gas content as shown thus:

$$
\mathrm{GIP}=\mathrm{GC} \_\mathrm{L} * \mathrm{CT}_{\mathrm{P}} \mathrm{A} * \mathrm{~A}
$$

Alternatively, GIP can be estimated as

$$
\begin{gathered}
\mathrm{GIP}=\mathrm{GAS} \text { CONTENT } \times \text { COAL THICKNESS } \mathrm{x} \text { AREA } \mathrm{x} \\
\text { Coal density }
\end{gathered}
$$

Similarly, coal tonnage is deduced as

$$
\mathrm{CTpA}=1359.7 * \mathrm{~h} * \mathrm{RHOB}
$$

\section{RESULTS ANALYSIS}

\subsection{Case 1: Coalbed Methane Model with Vertical} Well

The coalbed methane gas simulation model from Onyeama coalbed reservoir and its possible recovery efficiency using a vertical well orientation is simulated in this scenario. The well was made to flow in January 2015 and 25 years forecast was made with gas well production control rate, produced water rate, economic constraints of minimum gas rate, expected gas recovery, bottomhole pressure and recovery factor of 100MMSCF/DAY, 100STB/DAY, 5MSCF/DAY, 6501.8075MMSCF, 200PSIA and 4.99\% respectively. 

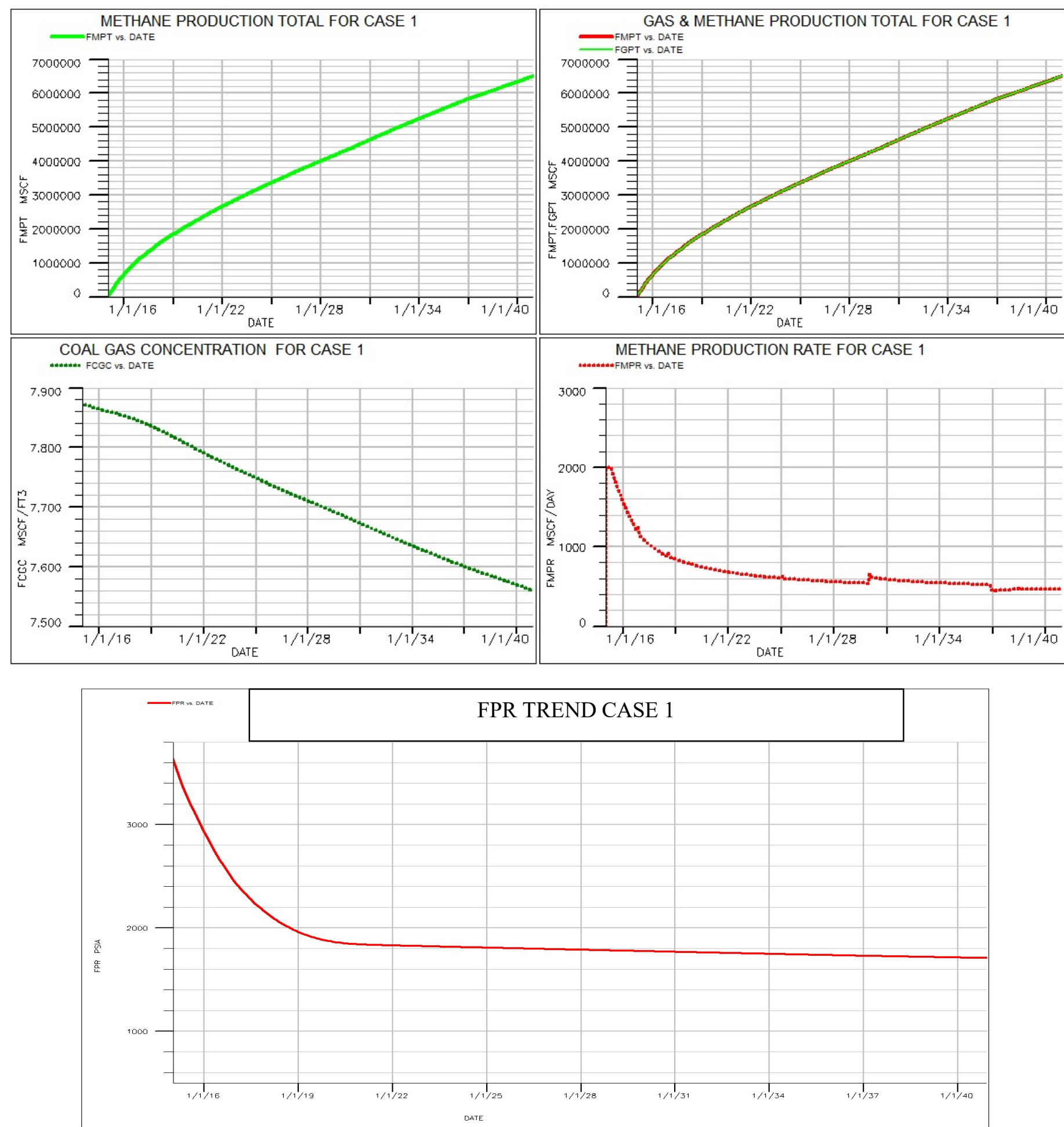

Fig-1: Showing simulated result of pressure, gas rate, coal concentration \& cumulative coal methane gas produced for vertical well

\subsection{Case 2: $\mathrm{CO}_{2}$-ECBM model With vertical Well (CO-ECBM-VW)}

This case is an enhanced coalbed methane recovery method using carbondioxide in a vertical well. The process involves injection and production wells. The carbondioxide is injected into the coal bed reservoir through an injection well at an injection rate of $1000 \mathrm{MSCF} / \mathrm{DAY}$. Twenty five years forecast was made with economic constraints of minimum gas rate of $5 \mathrm{MSCF} / \mathrm{DAY}$, total methane gas recovered of 10466.68MMSCF and recovery factor of $8.03 \%$. The reservoir pressure, methane gas rate, coal concentration and cumulative coalbed methane gas produced in carbondioxide enhanced coalbed methane production in a vertical well is shown in figure 2 

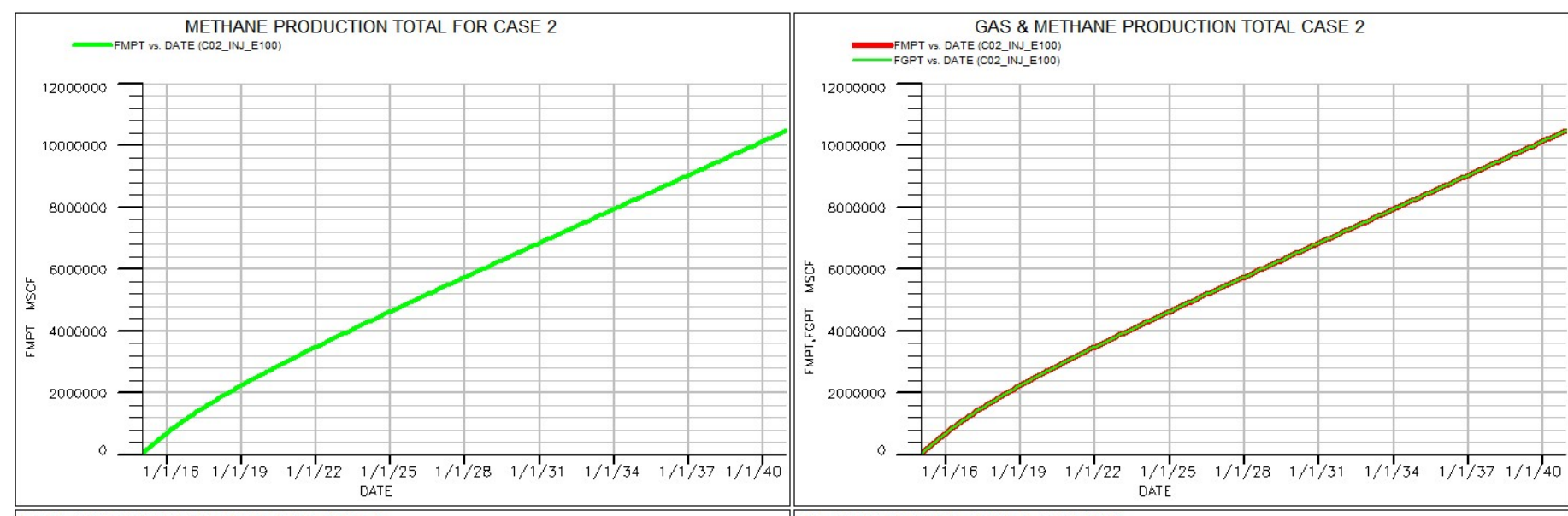

COAL CASE CONCENTRATION FOR
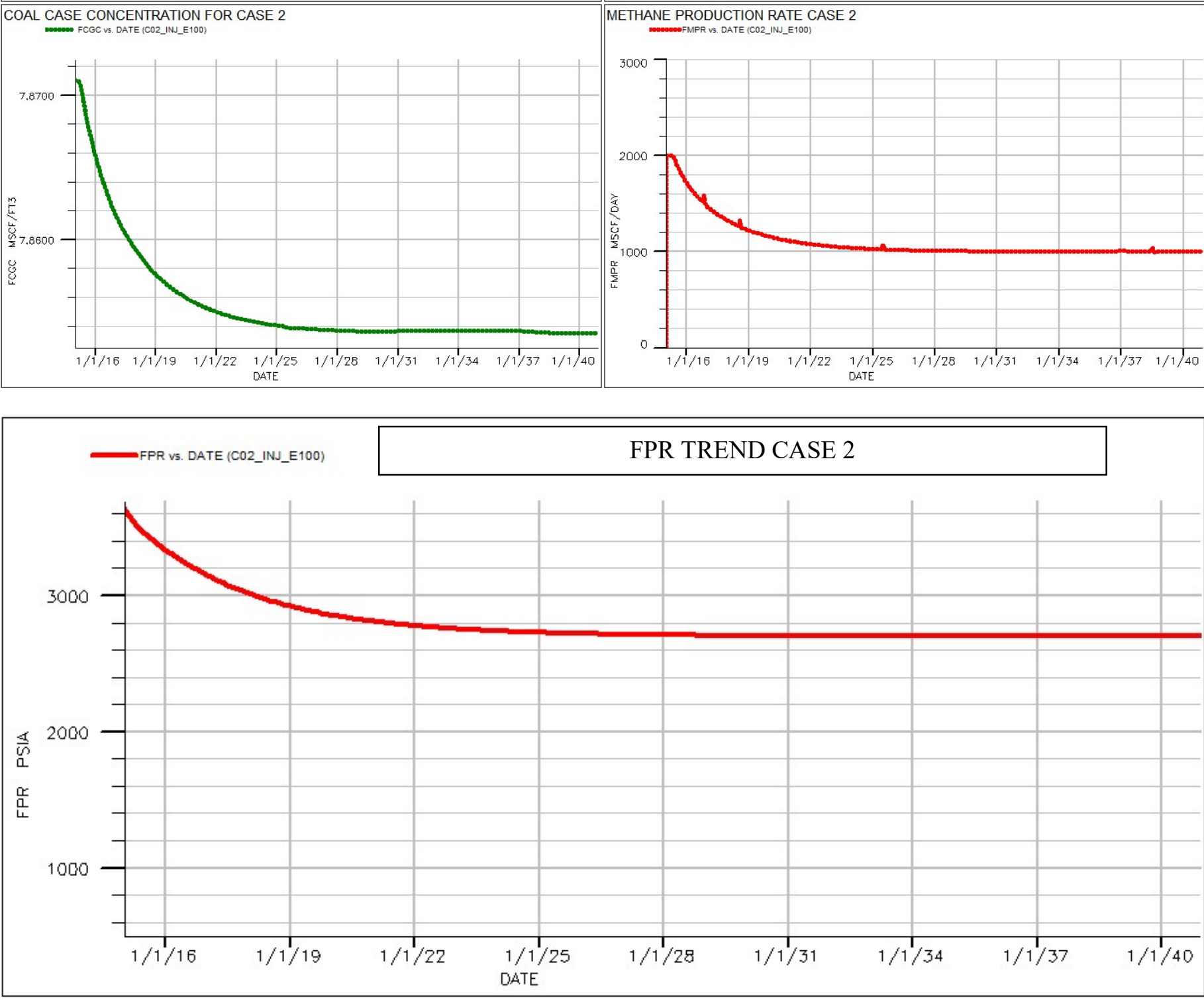

Fig-2: showing the pressure, gas rate, coal concentration and cumulative coal methane gas produced in carbondioxide enhanced coalbed methane in vertical well

\subsection{Case 3: Coalbed Methane Model with}

\section{Horizontal Well}

Horizontal 1 coalbed methane production well analysis was evaluated in a similar manner as the vertical well analysis stated above by using Eclipse 300 simulator for analysis of future production. Expected gas recovery and recovery factor at the end of forecast are 19866.1MMSCF and $15.2 \%$ respectively 

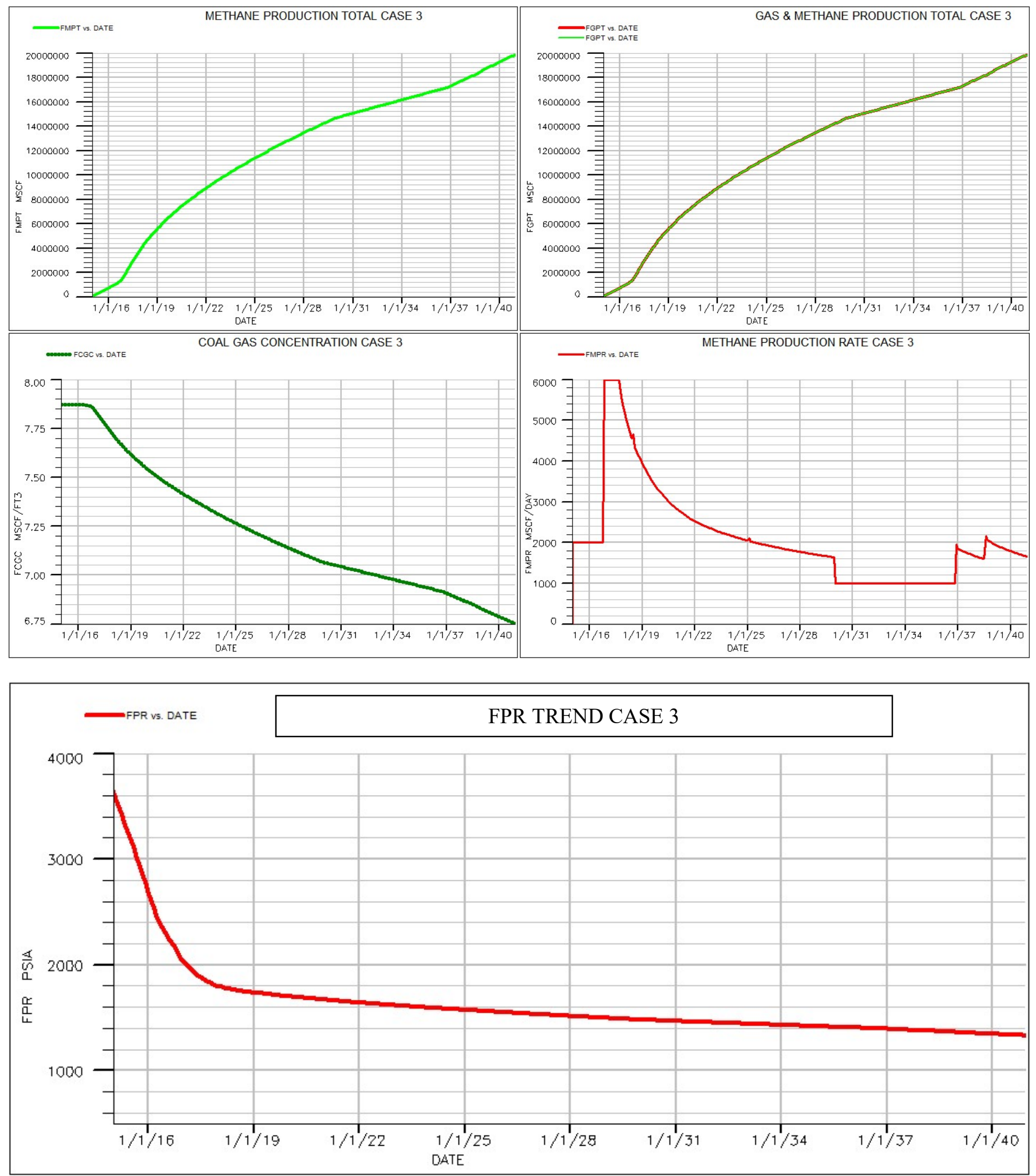

Fig-3: Showing simulated result of pressure, gas rate, coal concentration \& cumulative coal methane gas produced for horizontal well

\subsection{Case 4: $\mathrm{CO}_{2}$-ECBM model With Horizontal Well ( $\mathrm{CO}_{2}$-ECBM-HW)}

Horizontal well coalbed methane simulation was also enhanced using carbondioxide(ECBM). Similarly, twenty five years forecast was made with economic constraints with injection rate of $1000 \mathrm{MSCF} / \mathrm{DAY}$ and minimum gas rate of $5 \mathrm{MSCF} / \mathrm{DAY}$ to yield total methane gas recovered of 45648.42MMSCF and recovery factor of $35.04 \%$. 

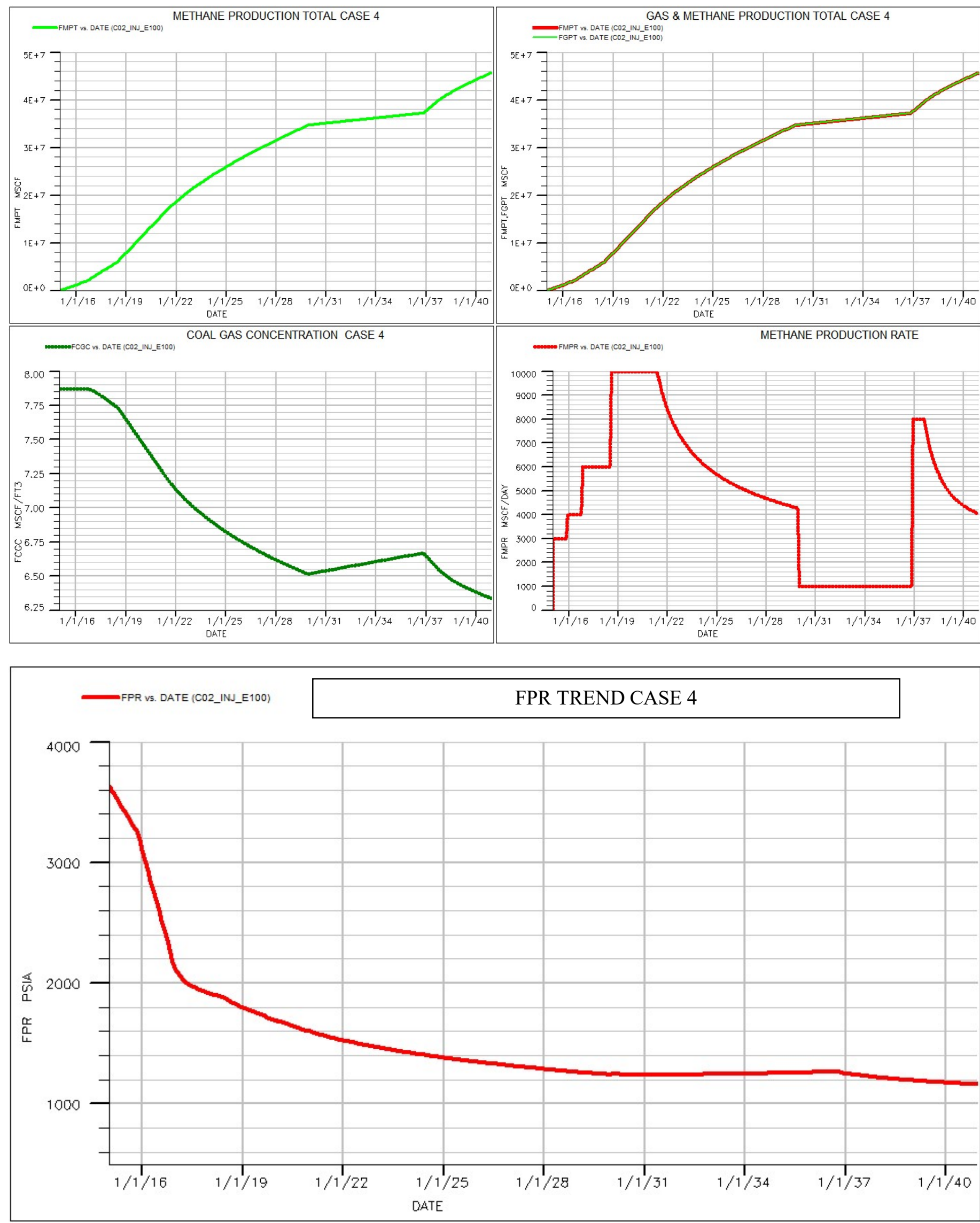

Fig-4: shows the pressure, gas rate, coal concentration and cummulative coal methane gas produced with horizontal well carbondioxide enhanced coalbed methane production of Onyeama field 


\section{DISCUSSIONS}

Carbondioxide enhanced coalbed methane production was envisaged and analysed due to increase demand for energy usage worldwide. Onyeama coalbed field analyses of both $\mathrm{CO}_{2}$-ECBM and CBM with coal gas concentration depletion plots for the different scenarios are highlighted. The coalbed methane concentration depletion or de-concentration trends for all four cases are shown in Figure 5 with $\mathrm{CO}_{2}$-ECBM-
VW gives the highest coal gas concentration or least deconcentrated coal gas with concentration of $7.854 \mathrm{Mscf} / \mathrm{ft}^{3}$ and recovery factor of $8.03 \%$ after 25 years of production, while $\mathrm{CO}_{2}$-ECBM-HW shows the least coal gas concentration of $6.35 \mathrm{Mscf} / \mathrm{ft}^{3}$ with the recovery factor of $35.04 \%$.

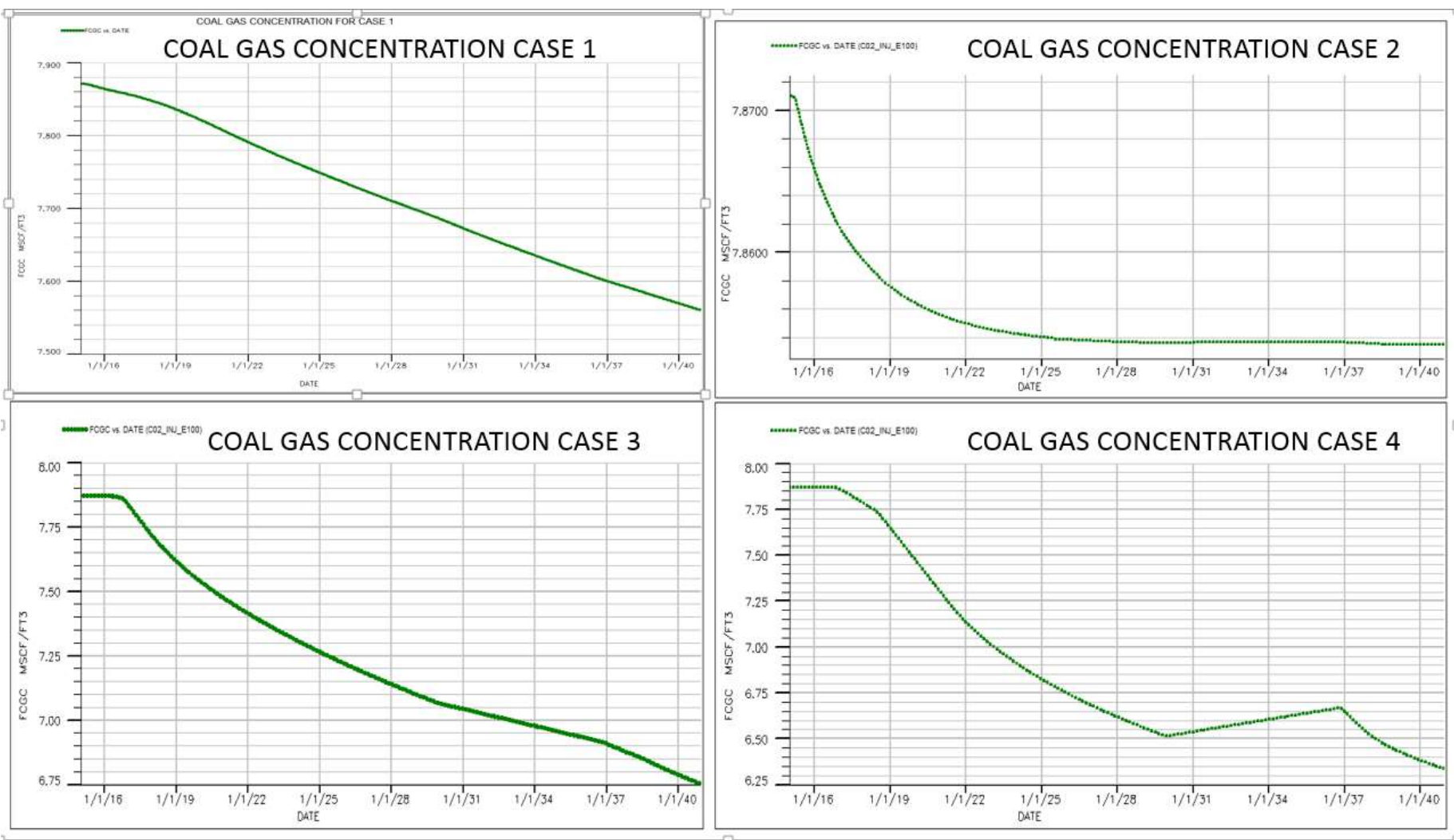

Fig-5: shows the coalbed methane concentration depletion or deconcentration trend for all the four case scenarios

The summary of the simulation results are shown in Table 1 for better understanding, comparison and analysis of $\mathrm{CO}_{2}$-ECBM and CBM in terms of recovery factor, coal concentration and cummulative gas production from the well after 25 years.

Table-1: Result Analysis

\begin{tabular}{|c|c|c|c|c|c|}
\hline & $\begin{array}{l}\text { CASE } 1 \\
\text { VERTICAL } \\
\text { WELL }\end{array}$ & $\begin{array}{l}\text { CASE 2 } \\
\text { VERTICAL } \\
\text { WELL }+\mathrm{CO}_{2}\end{array}$ & $\begin{array}{l}\text { CASE } 3 \\
\text { HORIZONTAL } \\
\text { WELL }\end{array}$ & $\begin{array}{l}\text { CASE } 4 \\
\text { HORIZONTAL } \\
\text { WELL + } \mathrm{CO}_{2}\end{array}$ & REMARKS \\
\hline $\begin{array}{l}\text { Recovery } \\
\text { Factor (\%) }\end{array}$ & 4.99 & 8.03 & 15.2 & 35.04 & \multirow{3}{*}{$\begin{array}{l}\text { Coal gas de-concentration and } \\
\text { recovery factor of each case are } \\
\text { subject to the development } \\
\text { methods employed in each cases. } \\
\text { Hence they are used as measures } \\
\text { for selecting the best development } \\
\text { option }\end{array}$} \\
\hline $\begin{array}{l}\text { Coal } \\
\text { Concentration } \\
\text { After Predictions } \\
\left(\mathrm{MSCF} / \mathrm{Ft}^{3}\right)\end{array}$ & 7.56 & 7.854 & 6.75 & 6.35 & \\
\hline $\begin{array}{l}\text { Volume Of Gas } \\
\text { Produced After } \\
25 y r s \\
\text { (MMSCF) }\end{array}$ & $6,501.81$ & $10,466.6$ & $19,866.1$ & $45,648.42$ & \\
\hline $\begin{array}{l}\text { Development } \\
\text { Scenario } \\
\text { Ranking }\end{array}$ & $4^{\text {th }}$ & $3 \mathrm{rd}$ & $2^{\text {nd }}$ & $1 \mathrm{st}$ & \\
\hline
\end{tabular}




\section{CONCLUSION}

Carbondioxide enhanced coalbed methane $\left(\mathrm{CO}_{2}-\mathrm{ECBM}\right)$ provides dual benefits of enhancing coalbed methane recovery and carbon sequestration. Thus, this investigation and study of $\mathrm{CO}_{2}$-ECBM on Onyeama coalbed field is therefore necessary to ascertain the viability, development and improve methane gas production from Onyeama coalbed field. $\mathrm{CO}_{2}$-ECBM simulation results in vertical and horizontal well orientations shows higher recovery factor when compared with CBM production of the same well orientation. Also, the $\mathrm{CO}_{2}$-ECBM-HW gives maximum recovery factor of $35.04 \%$ compared to other production platform for simulation predictions of 25 years. Hence, this study shows that Nigeria possess the ability to contribute effectively to global energy needs by harnessing the potential of unconvectional resource in various coalbed fields located in Nigeria.

\section{NOMENCLATURE}

$\mathrm{CT}_{\mathrm{P}} \mathrm{A}$ : Coal tonnage per acre

H: Coal thickness, feet

RHOB: minimum bulk density in the coal, $\mathrm{g} / \mathrm{cc}$

GIP: Gas in Place

GC_L: Langmuir gas content scf/ton

A: Total area in acres

$\mathrm{CT}_{\mathrm{P}} \mathrm{A}$ : Coal tonnage per Acre

GC_L : Langmuir desorbed gas content, scf/ton

$\mathrm{L}_{\mathrm{C}}:$ Langmuir gas content scf

$\mathrm{M}_{\mathrm{C}}$ : Moisture content in coal $\%$

$\mathrm{A}_{\mathrm{C}}$ : Ash content in coal $\%$

$\mathrm{P}_{\mathrm{C}}$ : Langmuir Pressure Psia

$\mathrm{P}_{\mathrm{R}}$ : Reservoir Pressure Psia

CBM : Coalbed methane

ECBM : Enhanced coalbed methane

$\mathrm{CO}_{2}$-ECBM: Carbondioxide enhanced coalbed methane

$\mathrm{CO}_{2}$-ECBM-VW: Carbondioxide enhanced coalbed methane from vertical well

$\mathrm{CO}_{2}$-ECBM-HW: Carbondioxide enhanced coalbed methane from horizontal well

\section{REFERENCES}

[1]. Abu, R.N., Mbanefo, I. O., and Adeloye, O. M. (2016): Coalbed Methane Production in Nigeria: Onyeama Coalbed, International Journal of Scientific and Engineering Research, Vol 7, No 11, 377-378

[2]. Mathews, J. P. and Kumar, H. (2006): An Overview of Current Coalbed Methane Extraction Technologies, Department of Energy and Mineral Engineering \& EMS Energy Institute, the Pennsylvania State University, University Park, PA-16802, USA, 1-5

[3]. Siemek, J., Rychlicki, S. and Rybicki C. (2006): Perspectives of Methane Recovery from Coal Beds in Poland, 1-2

[4]. Ojha, K., Karmakar B., Mandal, A. and Pathak, A.K. (2011): Coal Bed Methane in India, Difficulties and
Prospects, International Journal of Chemical Engineering and Applications Vol. 2, No. 4, 1-2

[5]. Young, G. (2009): Coalbed Methane Development - A Vital Part of the Total Energy Mix. Production Enhancement, Halliburton. USA, 5-6.

[6]. Coal Mine Methane Global Overview, (2006): Report by the U.S. Environmental Protection Agency Coalbed Methane Outreach Program.

[7]. Behre, D., (2006): Feasibility of Nigerian Coal Resources Development, Ministry of Solid Minerals Development, Federal Republic of Nugeria. http://www.globalmethane.org/documents/toolsres_coal_ov erview_ch 24.pdf(2004)

\section{BIOGRAPHIES}

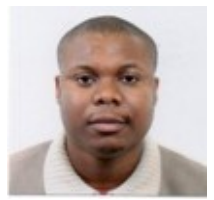

Abu Robin Nyemenim is a Certified Mechanical Engineer by the Council for the Regulation of Engineering in Nigeria. He is currently undertaking PhD study in Energy at the Cranfield University, Cranfield, Bedfordshire, United Kingdom and holds Master of Science in Offshore and Ocean Technology with Subsea Engineering from the Cranfield University and Bachelor of Technology degree in Mechanical Engineering from the Rivers State University of Science and Technology, Port Harcourt. He is a member of professional associations such as the Nigerian Society of Engineers and the Nigerian Institution of Mechanical Engineers and has publications in reputable international journals.

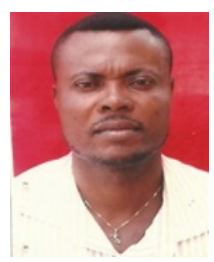

Cyrus Aseibichin is currently undertaking $\mathrm{PhD}$ study in Chemical Engineering from the Rivers State University of Science and Technology, Port Harcourt. He holds Master of Engineering in gas Engineering from the University of Port Harcourt and Bachelor of Technology degree from the Rivers State University of Science and Technology, Port Harcourt. He is a certified Chemical Engineer by the Council for the Regulation of Engineering in Nigeria and member of the Nigerian Society of Engineers.

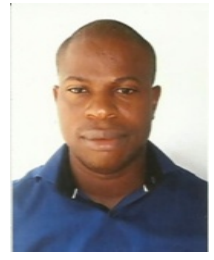

Adeloye Olalekan Michael is currently undertaking $\mathrm{PhD}$ degree in Chemical Engineering at the Rivers State University of Science and Technology, Port Harcourt. He holds Master of Engineering in Petroleum Engineering(Reservoir option) from the University of Port Harcourt and Bachelor of Technology in Chemical/Petrochemical Engineering from the Rivers State University of Science and Technology, Port Harcourt. He is a certified Chemical Engineer by the Council for the Regulation of Engineering in Nigeria with publications in reputable international journals and member of professional associations such as the Nigerian Society of Engineers, Nigerian Society of Chemical Engineers and Society of Petroleum Engineer. 
Wilcox Ziebiye Zaccheaus is a certified Chemical Engineer by the Council for the Regulation of Engineering in Nigeria and member of the Nigerian Society of Engineers. He holds Bachelor of Technology degree in Chemical/ Petrochemical Engineering from the Rivers State University of Science and Technology, Port Harcourt and currently undertaking Master of Technology degree in Chemical Engineering from the same institution. 